\title{
Research and Analysis on English Teaching Reform in Higher Vocational Colleges from the Perspective of Professional Competence Cultivation
}

\author{
Yifan Zhu, Rong Hu \\ Jiangxi Technical College of Manufacturing 330095, China
}

Keywords: professional competence cultivation; higher vocational college; English teaching; teaching mode reform

\begin{abstract}
With China's accession to the World Trade Organization, English has become the main language of international market communication. Therefore, training students' oral English and ability to use English are of great significance to the development of society. In view of the current situation, how to improve the professional competence of English Teaching in higher vocational colleges has become a major research topic. From the perspective of professional competence training, it has become the focus of current English teaching to improve the English level of vocational college students.
\end{abstract}

\section{Introduction}

With the acceleration of economic globalization, there is a growing demand for practical talents with English application ability from society. The vigorous development of Higher Vocational Education in China has trained a large number of Applied English talents for all sectors of society. However, because of the low level of students' English in higher vocational colleges, it is difficult to meet employers' standard, and students in higher vocational colleges are mostly incompetent to meet the needs of business positions. The main reason to cause this phenomenon is that there are some common problems in the English teaching mode. In the actual English classroom teaching, teachers only pay attention to the explanation of theoretical knowledge in teaching materials but ignore the practice of English teaching. Therefore, in view of this phenomenon, higher vocational colleges are expected to actively innovate and reform education and teaching mode, change teaching idea, improve teaching environment and alter backward education methods, so as to improve students' English proficiency in an all-round way.

\section{The Importance of Higher Vocational English Teaching Mode Reform from the Perspective of Professional Competence Cultivation}

In the process of promoting education and teaching in China, the reform of educational system should go towards the scientific development direction. The traditional education in our country stresses students' study of theoretical knowledge, but neglects the cultivation of their practical ability, which seriously causes students to be incompetent to apply theoretical knowledge in time to concrete practice. However, a new round of curriculum reform in China clearly suggests that in the actual education and teaching, we should combine theoretical knowledge with social development. Higher vocational colleges are required to timely update their teaching contents in accordance with the dynamics of social development. Teachers need to actively change their roles in teaching, put students in the main position, and apply a variety of teaching methods to promote the development of students' creative thinking ability in the actual classroom teaching. Since the strengthening of students' theoretical knowledge and practical application ability is the specific requirement of the current new curriculum reform ${ }^{[1]}$.

As a basic teaching course, English plays an important role in the development of contemporary society. Especially for the future employment of vocational college students, English plays an indispensable role. At present, the English level of higher vocational education is generally low. Based on the current situation of English teaching, higher vocational colleges have tried to innovate 
and reform English teaching mode. In the actual English reform, it is expected to combine the characteristics of current English teaching and the differences of students' English foundation, so as to consider the problem in all aspects. Moreover, it is necessary to strive to build a curriculum development strategy centered on "professional competence", determine the future employment direction of vocational college students, as well as the competence required by employment position. Only by insisting on the innovation of English teaching mode from actual conditions can we cultivate high-quality and high level omnipotent talents who are able to meet the needs of career development.

\section{Problems in English Teaching of Higher Vocational Colleges at Current Stage}

As a language course, English mainly develops students' oral expression ability, written expression ability, and English communicative ability. The main purpose of English teaching is to enhance students' practical communication ability. However, in the practice of English Teaching in higher vocational colleges, English teachers are shackled by traditional teaching ideas, ignoring the actual application value of English. Most English teaches do not put the purpose of English teaching into practice and make English teaching limited to all kinds of examinations. This not only hinders the improvement of students' English learning ability, but also pushes the development of Higher Vocational English teaching to utilitarianism. Therefore, current backward English teaching concept, to a certain extent, has suppressed the improvement of students' English comprehensive ability and neglected the demand for the comprehensive ability of English, which seriously hindered the successful development of students' future work.

At present, in the course of English teaching, higher vocational colleges pursue sheer students' learning of English theoretical knowledge, ignore the cultivation of their English practical ability, and have not realized the importance of professional competence training in Higher Vocational English classroom teaching. In the course of teaching English in some higher vocational colleges, under the influence of traditional teaching ideas, teachers still pay more attention to the explanation of key knowledge in books, and do not stress students' ability to learn, read and write, let alone involve specific majors of students. The backward teaching mode of teachers will increase students' learning burden, and there is no practical significance for the improvement of their English comprehensive ability. The contents of English Teaching in higher vocational colleges do not conform to the needs of social development, and has a serious disconnection with the reality of social development, which has led to the low efficiency of English teaching.

At present, the teaching of English in higher vocational colleges still adopts the traditional teaching methods. When teachers carry out English teaching, they only pay attention to the explanation of grammar, vocabulary and syntax in books without a good interaction with students, nor do they put students in the subjective position. English teachers are still using the indoctrinization method, ignoring the fact that students are the main body of the classroom. In addition, English teachers can not sublimate book knowledge, but just copy books. This kind of teaching method has seriously hindered students' English learning ability and fails to meet the needs of higher vocational colleges.

\section{English Teaching Reform Strategies in Higher Vocational Colleges from the Perspective of Professional Competence Cultivation}

In practice teaching, English teachers in higher vocational colleges should ensure that teaching methods keep pace with the times, thus effectively promoting the training of students' professional ability. In the perspective of teaching methods, teachers are expected to actively adopt the situation teaching method, case teaching method and so on. Through situational teaching, teachers can set up appropriate problem situations in class to stimulate students' thinking ability. In addition, English teachers should combine English teaching with the social development in accordance with the needs of the current social development. According to the actual situation in the workplace, they can extend related teaching and expand students' comprehensive ability. In terms of teaching methods, 
teachers are expected to integrate modern information technology into practical teaching and pay attention to the application of multimedia technology in teaching. It is feasible to use the Internet technology to establish a higher vocational English online learning platform, effectively guaranteeing students' English learning.

Based on the current situation, some vocational colleges still adopt the traditional mode of evaluation. Influenced by the traditional examination oriented education, higher vocational colleges take score as the standard to measure students' English level. In short, teachers regard English theoretical achievements as the only standard to measure students' English ability, and they do not take practical ability as the measurement. Such a single evaluation method can not accurately test the true level of students, since only practice is the sole criterion for testing truth. Higher vocational colleges should change their traditional backward evaluation methods and actively build diversified evaluation systems, so as to make their assessment and evaluation more comprehensive. English assessment standards must develop in the direction of innovation, application, expression and social practice, improve the current assessment mechanism, and strive to build a diversified evaluation method, thus promoting the improvement of students' English comprehensive ability.

In English classroom teaching, teachers should be clear about the purpose of English teaching, which is, in essence, for students' future career. Based on this, English teachers are expected to integrate English knowledge and professional knowledge according to the actual situation of teaching and the characteristics of students' English learning, gradually infiltrate professional knowledge into English teaching, establish students' correct awareness of English learning, as well as make it clear that English learning is for professional services, so as to effectively promote students' learning ability and enhance their comprehensive ability.

English teachers in higher vocational colleges have not realized the importance of combining English knowledge with professional knowledge for students' future career. In the actual teaching, they still adopt the traditional backward education and teaching mode, paying attention to the basic theoretical knowledge learning of grammar and sentence, but neglect the cultivation of students' listening, speaking, reading and writing abilities. In carrying out the teaching work, they did not realize the importance of the training of students' practical ability, which seriously caused the appearance of "high score but low competence". Therefore, in view of the current situation, English teachers should change their teaching ideas, reform teaching methods, and make use of modern information technology to enrich the contents of English classroom teaching, so as to effectively improve students' English learning effect.

At present, in order to achieve efficient English Teaching in higher vocational colleges, it is necessary to integrate it with professional contents. According to the contents of English teaching, teaching is divided into several modules, and each module should correspond to students' different professional backgrounds. During teaching, it is supposed to set up relevant teaching activities according to the needs of current posts. Teachers use modular teaching to cultivate students' English training in professional situations, so as to enhance their comprehensive English ability. In addition, students are required to learn the contents of each module and combine their own learning characteristics to maximize their knowledge, so as to achieve the purpose of applying knowledge to practice. Moreover, students should also insist on applying the knowledge of English theory to practical practice, because practice is the only standard to test the truth. Only through practical activities can students' learning effect be accurately tested.

The cultivation of students' professional ability largely depends on a good mechanism. Innovation is a kind of challenge to the tradition. Higher vocational colleges should reform and reform their English education and teaching system, so as to clear up obstacles for English Teaching. In actual teaching, teachers must pay attention to reform and innovation as well as learn to draw inferences from others. Good mechanism can not only improve students' English learning ability, but also improve their teaching effects. In addition, higher vocational colleges and universities must pay attention to the cooperation with social enterprises, strengthen communication with enterprises, and improve students' professional skills in accordance with the standards required by market talents, thus effectively helping students to improve the level of English comprehensive ability. 


\section{Conclusion}

Higher vocational colleges are an important part of the field of education in our country. In the course of English teaching, teachers should pay more attention to the training of students' professional ability, fully mobilize the existing teaching elements, and bring more new vitality into the professional competence cultivation of English students in higher vocational colleges. In addition, teachers are expected to constantly change their teaching ideas, reform teaching methods, reform teaching mode, and integrate modern information technology into practical teaching effectively, so as to effectively cultivate students' English comprehensive ability.

\section{Acknowledgements}

The work was supported by the Youth project of humanities and social sciences research project in Jiangxi Province in 2016, with the project number JC162025. and the project name entitled: Current Situation Investigation and Countermeasures of Cultivating the Intercultural Communicative Competence of Flight Attendant Students in Higher Vocational College

\section{References}

[1] Liu Li. Reform Method of English Teaching Mode in Higher Vocational Colleges from the Perspective of Professional Competence Cultivation [J]. Teaching and Educating People (Higher Education Forum), 2018 (18): 104-105.

[2] Hao Lian Chun. "Modular” Teaching Mode Reform of Higher Vocational English Based on the Perspective of Professional Competence Cultivation [J]. Higher Education Journal, 2017 (24): 176-178.

[3] Zhang Le. Reform Method Analysis of English Teaching Mode in Higher Vocational Colleges Based on the Perspective of Professional Competence Cultivation [J]. Intelligence, 2017 (32): 39.

[4] Bao Yingchao. Reform of English Teaching Mode in Higher Vocational Colleges from the Perspective of Professional Competence Cultivation [J]. Journal of Liaoning Higher Vocational Education, 2017, 19 (01): 38-40.

[5] Zhu Xiaowei. Reform Methods of English Teaching Mode in Higher Vocational Colleges from the Perspective of Professional Competence Cultivation [J]. Adult Education in China, 2015 (04): 138-140.

[6] Liu Yun, Zhang Bo. Teaching Reform of Computer English in Higher Vocational Colleges from the Perspective of Professional Competence Cultivation [J]. Wireless Interconnected Technology, 2014 (04): 249+251.

[7] Wu Yaqin. Exploration of Business English Teaching Reform in Vocational Colleges from the Perspective of Professional Core Competence Cultivation [J]. Journal of Harbin Vocational and Technical College, 2013 (03): 37-38. 